\title{
THE POSSIBILITIES OF MEDIATION TO RESOLVE ADMINISTRATIVE CONTRADICTIONS AND CONFLICTS
}

\author{
Ivanka Bankova ${ }^{1 *}$, Denislava Angelova ${ }^{2}$ \\ ${ }^{1}$ Assict. Prof. Ph.D. Chernorizetc Hrabar Varna Free University, Varna, Bulgaria, \\ bankova.v@gmail.com \\ ${ }^{2}$ Ph.D. Chernorizetc Hrabar Varna Free University, Varna, Bulgaria, \\ denislava.angelova@gmail.com \\ ${ }^{*}$ Corresponding Author
}

\begin{abstract}
The article presents the results of a study in which the subject of research were the possibilities for mediation to solve administrative contradictions and conflicts. Mediation and mediation process in Bulgaria have significant development, both in the demand for mediation services and in their implementation. The main advantages of mediation, which distinguish it from the resolution of conflicts by judicial means, are summarized. The limitations and disadvantages of the mediation process, faced by participants in a mediation procedure, are examined. The mediation procedure should be based on statutory principles, with most of them internationally accepted and present in the legal framework of mediation in different countries around the world.
\end{abstract}

Keywords: volunteering, innovation, institutional regulation, social activity, socially useful behaviour model.

\section{INTRODUCTION}

Mediation is one of the specific methods of conflict management and resolution, assisted by the participation of a mediator conducting negotiations between the parties involved and enabling Alternative Dispute Resolution (ADR). It includes a procedure in which a third, neutral person assists the parties in resolving their dispute. ADR emerged as an alternative to legal proceedings and enables disputing parties to achieve greater speed, cost saving and efficiency in finding a solution compared to traditional litigation (Po Allahverdova, Karpenko, 1999). The idea and practice of mediation existed since antiquity. In modern conditions and characteristics of socio-economic and administrative relations, mediation practice is becoming increasingly important. The main reason for this is the increased need for out-of-court settlement of diverse conflicts in type and nature. The advantages of ADR through mediation are associated with minimal formality, privacy, discretion, confidentiality and friendliness, control over process and resolution by the parties in the dispute, use of experts, possibility to settle the dispute on the principle of fairness and based on the interests of parties.

\section{SCIENTIFIC AND THEORETICAL DESCRIPTION OF THE PROCESS “MEDIATION"}

According to UK Mediation, unifying English mediators and one of the most authoritative organisations in the world, "Mediation is a process by which an impartial third party helps two or more arguing parties resolve a particular conflict. It is the parties rather than the mediator that determine the terms of each agreement reached. Mediation is usually focused on the future, not on the past." (Liebmann, Marian, ed, 2000a) Some people believe mediation involves simply negotiations taking place with the participation of a third party. In 
reality, "The mediator seeks to help people negotiate in a more effective way than that they would do themselves. The mediator helps to find a solution that is more advantageous than conflict, to find the point of common interest, which lays the foundations of a creative but realistic resolution of the conflict." (Phillips, Barbara, 2001; Hasan, 2016a)

The following main advantages of mediation, which distinguish it from the resolution of conflicts by judicial means, can be highlighted:

- Positive concept of conflict - in mediation, conflict is perceived as something inseparable from the nature of man and society;

- Use of dialogue as a constructive response to aggression, avoidance and subordination;

- Cooperation - the attainment of common interests does not mean that each participant cannot achieve its specific interests;

- Development of the ability of self-regulation and self-control, which helps parties to adopt independent solutions, taking into account the peculiarities of the social environment in which they live;

- Democratic and equal participation that emphasises the importance of the opinions, feelings, desires and necessity of all participants in the process, with responsibility for resolving the conflict equally shared among all parties;

- Mutual understanding and empathy, which means giving the necessary attention to the parties and developing the ability of the mediator to put himself in their place. This helps to reach the understanding of the causes and different perceptions of opponents about aspects of the same reality;

- Active involvement of the parties in the conflict - the parties are able to define their interests and cooperate to reach them, and in such cases, achieving a successful resolution of the conflict is more likely.

\section{PREREQUISITES FOR THE DEVELOPMENT OF MEDIATION AND MEDIATION PROCESS IN BULGARIA}

It is necessary to note that the joint and voluntary reaching a decision between the parties with the help of the mediator has no legal force, it is based on moral and ethical principles and norms. Practice shows that most agreements reached in a mediation procedure are respected consciously and voluntarily. This is probably the prerequisite for mediation and mediation process in Bulgaria to have significant development, both in the demand for mediation services and in their implementation. (Hasan, 2018b; Petrova, Petrov, 2020a) In the last few years, the overburdened courts have begun to refer cases, that can be resolved by agreement, to a mediator. In confirmation of this comes the created in 2015 Centre of Mediation at the Regional Court - Varna.

Participants in a mediation procedure in Bulgaria face the following limitations and disadvantages of the mediation process:

- Mediation is not applicable in resolving conflicts related to violations of laws and criminal conflicts.

- Mediation is not applicable in individuals who are unable to adequately and rationally perceive reality (due to health and other problems). Mediation is not able to change the personality or value attitudes of its participants.

- Unlike the judge, the mediator has absolutely no authority to impose his opinion and decision on the parties in the conflict. By presumption and by law, the mediator is neutral. The mediation procedure is voluntary and participants in the process can opt out at any stage of its course.

- Unlike the judicial system, mediation is not intended to rule who the right belongs to, nor is it debating for the purpose of proving the rights of the parties or persuading the opponent to step away from the position he considers important. Mediation does not aim to end with a winner and a defeated.

- The mediation procedure does not always end favourably for the parties, although practice shows that about $80 \%$ of cases reach an acceptable solution for them.

- The mediation process puts high demands on the qualities of the mediator. An important condition for his successful practice is that he possesses complex knowledge in different areas of public reality, with this knowledge being supported by extensive practical and life experience, high emotional resilience and poise.

- Mediation and mediation process can be successful when both parties tend to find a common interest and 
a solution that satisfies them. If the parties participate against their will, the mediation procedure is doomed to failure.

Mediation is a peculiar type of conversation aimed at finding a favourable solution to a real problem. The discussions that take place in mediation are different, for example, from the free conversations held in connection with the dispute. It can be implemented through various techniques and tactics implemented by the mediator, including establishing rules of negotiations, calming the conversation, clarifying the problem issues, asking questions to help better understand the problems, interests and options for solutions. The help of the mediator is not a guarantee of a successful outcome. The success of mediation depends primarily on the will of the parties (Petrova, Petkova-Georgieva, 2020b).

\section{LEGALLY REGULATED PRINCIPLES OF MEDIATION}

In order to successfully implement the purpose of mediation, it is necessary that the mediation procedure be based on statutory principles. Most of them are internationally accepted and are present in the legal framework of mediation in most countries in the world where there is such a framework. Such principles are:

Free will (Article 5 of MA) - the Parties are involved in the procedure of their own accord and may withdraw at any time. It is ensured by the possibility of either Party to terminate the procedure.

Equality (Article 5 of MA) - each of the parties has equal opportunities for participation in the mediation procedure. It is ensured by provision of equal opportunities for participation in the procedure - equality in meetings with the mediator, as well as in the hearing, and discussions on the participation of legal aides of the parties (Madiation Act. Pibl. 2000b).

Neutrality (Article 6 of MA) - the mediator does not impose a decision on the dispute. All matters in the mediation procedure shall be settled by mutual agreement of the parties.

Impartiality (Article 6 of MA) - the mediator does not exhibit bias. Neutrality and impartiality are ensured by the obligation of the mediator to declare whether there is a conflict of interests by signing a declaration of impartiality at the beginning of the procedure, as well as by the possibility of withdrawal of the mediator on his/her initiative or at the request of any of the parties.

Privacy (Article 7 of MA):

- Internal confidentiality - the mediator may not communicate circumstances entrusted to him by one of the parties to the dispute to the other participants without the consent of the party that disclosed the relevant information.

- External confidentiality - participants in the procedure are obliged to keep secret all circumstances, facts and documents, which became known to them in the course of the procedure.

Privacy is ensured in several ways:

- The parties and the mediator sign an agreement on mediation containing a confidentiality clause of the procedure and a commitment to its compliance;

- Lawyers or other experts involved in the procedure shall sign a statement of confidentiality;

- The mediator may not be questioned as a witness about circumstances that are entrusted to him by the participants and are relevant for resolving the dispute being subject of mediation, except with the explicit consent of the participant who trusted them.

Exception from the confidential nature of mediation is allowed in cases explicitly specified in the law that are related to the needs of the criminal process, protection of public order, protection of the interests of children, prevention of violence, etc (Hasan, 2016b).

\section{SPECIFIC FEATURES AND STAGES OF THE MEDIATION PROCESS- SPECIFICITY OF MEDIATION PROCEDURE IN ADMINISTRATIVE DISPUTES AND CONFLICTS}

The mediation process consists of several logical stages, and the main ones are:

- Preliminary stage - initiation and preparation of the procedure.

- Opening.

- Definition of the disputed issues. 
- Investigation of the interests.

- Generating variants, evaluation and selection.

- Completion of the procedure - with or without agreement.

From a procedural point of view, mediation takes place in common and separate meetings - between the mediator and all parties together and separately with each party respectively. It is necessary to emphasize that mediation is an informal procedure, and any separation and definition of individual stages is conditional.

In a number of cases, the specifics of the mediation procedure in administrative disputes and conflicts are of interest.

Administrative law deals with the organization of state administration, as well as with the control of relations between state authorities and private persons. Specific judicial procedures have been implemented to resolve the disputes and conflicts that arise between them, which is the main guarantee of citizens' rights and administration. (Dimitrova, 2018a; Vassilev, Kavrakov, 2014)

In recent years, problems and difficulties in implementing judicial procedures have been growing. The courts are overwhelmed in general and in particular with administrative disputes, resulting in conflict with the rights of the parties to the dispute within the meaning of Article 6.1 of the European Convention on Human Rights, guaranteeing the right to hear the case within a reasonable time. (European Convention on Human Rights, 2019b) For some of the administrative disputes, it is inappropriate to apply judicial procedures because the latter are too formal, they lack flexibility and do not meet the need of the civil disputes to be resolved fairly, not only according to the strict legal rules.

In 2001 the Council of Ministers of the Member States adopted Recommendation No. R (2001) 9 of the Committee of Ministers at the Council of Europe and Directive 2008/52/, which regulate alternatives to litigation between administrative authorities and private persons, recommending that the governments of the member states encourage the use of mediation and alternative means of resolving disputes and conflicts between administrative authorities and individuals. Mediation can be used before court proceedings, but it can also be used during court proceedings, for example, at the suggestion of the judge. Although the Recommendation treats the resolution of disputes and conflicts between administrative authorities and individuals, mediation can also serve to prevent disputes and conflicts before their occurrence.

Alternatives to administrative court proceedings need to be selected where appropriate, especially in cases where they relate to separate administrative acts, contracts, civil liability, etc., related to financial claims. The choice of mediation as an alternative means of resolving the conflict takes into account the specifics of the particular dispute. It is important that the parties receive sufficient information on the possibility of using mediation, to ensure the fairness of the procedure, the independence and impartiality of the mediator, taking into account the inequalities of the parties and to encourage the completion of the procedure in a reasonable term.

\section{APPLICABILITY OF MEDIATION AS A WAY OF RESOLVING ADMINISTRATIVE DISPUTES AND CONFLICTS}

Despite its development, mediation is still very limited in resolving administrative disputes and administrative conflicts. Its limited application stems from the fact that, in administrative proceedings, where the legality of an administrative act is challenged, only the courts are capable of resolving the dispute.

In appeals against an administrative act of general effect, the assessment also belongs only to the court. The mediation procedure is applicable in cases of objections to an individual administrative act, as it aims to approximate the positions of the administrative body and the private person when proposing a solution. Whatever degree of conviction the mediator uses, the only one who can amend the administrative act is the authority that issued it. Mediation allows for contact between the administrative authority, the addressee and stakeholders, as well as for the adoption of an opinion on which everyone can agree (e.g. objection to a building permit). However, the relevance of mediation depends on the specifics of the particular dispute.

Mediation in resolving administrative disputes consists of the following specific elements:

- Achieving an agreement on the expediency of the administrative act.

- Possibility to suspend the contested administrative act - by law, by the court, by the issuing administrative authority.

- Provision of the implementation of the solution reached. 
- Right of the court to perform a review for the legality of the agreement.

In the Administrative Procedure Code (APC) there are texts pointing to this matter. Article 20 (1) provides that in the proceedings for contesting the individual and general administrative acts by administrative order an agreement may be concluded before the administrative body, if it does not contradict the law. The agreement may be signed between the Administrative Authority and the parties to the proceedings or only between the parties, but in both cases the Administrative Authority shall officialise it with its signature. The conclusion and approval of the Agreement makes the administrative act void. The agreement is concluded in writing and contains compulsory requisites within the meaning of Article 20 (5). If the agreement affects the rights or legitimate interests of a person who did not participate in its conclusion, the agreement shall not take effect until it has been approved by him/her in writing, and the written approval shall become an integral part of the agreement. The agreement replaces the administrative act (Vassilev, Tanev, Kavrakov, Abrashev, 2015).

According to the APC, an agreement can be concluded before the court (Article 178), in any stage of the case in the conditions under which it can be concluded before the administrative body and has the character of a court settlement. The court approves it by definition, if it does not contradict the law and is signed by all parties, and annuls the administrative act and terminates the case.

\section{ADVANTAGES OF MEDIATION IN RESOLVING ADMINISTRATIVE DISPUTES AND CONFLICTS}

As an alternative means of resolving administrative disputes, mediation can be applied both before and during legal proceedings. The following main advantages can be outlined:

- According to the APC, the administrative body can itself review its act (internal review).

- Speed and procedural economy.

- Reduction the workload of the courts and improve the administration of justice.

- Improvement of the business climate, the relations between institutions and the public, and of the trust of citizens in the administrative apparatus.

- The parties are saving time and money.

- Improvement of communication between the parties in the administrative relationship and reduction of tensions.

Mediation can be initiated by the parties or by the court and obeys the basic principles of mediation equality of the parties, impartiality and independence of the mediator. Regarding 'confidentiality', it must be consistent with the principle of unrestricted access to administrative documents. In the mediation procedure, administrative authorities should respect the principles of legality and neither they nor private persons can use it to evade their obligations.

\section{DIFFICULTIES IN APPLYING MEDIATION IN RESOLVING ADMINISTRATIVE DISPUTES AND CONFLICTS}

Some of the difficulties are related to regulatory challenges, such as the specified in Article 3 (1) of the MA, that mediation applies "to administrative disputes related to user rights". This is probably a mistake in the version of 2011 of the law, because if a detailed reading is not made, the belief remains that mediation is applicable only to disputes related to user rights. The law introduces a restriction not to conduct mediation if a law or other legal act provides for another order for the conclusion of an agreement, and with Article 20 the APC regulates the institute of the agreement. Another shortcoming is the lack of an explicit regulation for suspension of the preclusive terms for appealing an administrative act in case of initiated mediation procedure, as well as a provision for the administrative judges to guide the parties to the dispute toward mediation. Last but not least, there is no clear regulation on the negotiation powers of the administrative authority. (Bankova, 2019a)

There are also some factual obstacles, such as inequalities, in terms of power and subordination between the administrative authority and the parties in administrative acts, which do not favour contractual processes, whereas in mediation, the parties are equal. Another limitation is the insufficient operational autonomy of the administrative body. On a case-by-case basis, it is obliged to consider whether it is within its power to negotiate or not. It is also necessary to take into account the interests of third parties who would be affected by the agreement reached by mediation. An important feature is the obligation of the administrative authority 
to take the same decisions in similar cases thus, in a subsequent similar case, the same decision should be taken. Another duty of the administrative body is, when carrying out its activities and ordering its acts, to comply with the principle of transparency, which is contrary to the principle of confidentiality, one of the main features of the mediation procedure.

Despite some shortcomings, the advantages of out-of-court options for resolving administrative disputes and conflicts are indisputable. Unfortunately, at the present stage their application is not sufficient in the administrative and management practice. For their successful popularisation, it is necessary to improve the legal framework and conduct information campaigns to familiarize potential parties with the possibilities of mediation as an alternative method for resolving disputes of administrative nature. The implementation of mediation in administrative disputes has significant potential to restore citizens' trust in the administration and improve dialogue between them.

\section{CONCLUSION}

Mediation options for resolving administrative contradictions and conflicts are based on statutory principles. Most of them are internationally accepted and are present in the legal framework of mediation in different countries around the world. Mediator skills are extremely useful in the activities of administrative officers of different ranks. Applying them appropriately, they can, through the techniques of transformative mediation, resolve deep and hidden contradictions with external manifestations other than the essence of real problems hampering the work of the administrative structure. Last but not least, through mediation naturally new rules and patterns of relations are born and negotiated, which are clear, understandable and respected by the parties voluntarily, as they have come to their formulation.

\section{REFERENCE LIST}

Bankova, I. (2019a). Administrativna konfliktologiya. UI na VSU „Ch. Hrabar“. Varna. 2019, s. 136-137

Dimitrova, D. (2018a). Novite promeni v APK - stapka kam po-efektivno administrativno pravorazdavane. Parva Natsionalna nauchna konferentsiya „Pravoto i biznesat v savremennoto obshtestvo. Aktualni pravni predizvikatelstva v ikonomikata“, 9 noemvri 2018 g. Sbornik s dokladi. Izd. „Nauka i ikonomika“ IU - Varna. 2018. p. 413-424

European Convention on Human Rights (2019b) https://www.echr.coe.int/ Documents/Convention Bul.pdf (available on December 20, 2019)

Hasan Azis, (2016a). Qualitative Changes in Municipalities in the Absorption of Structural Funds and the Impact of Decentralization on Their Achievement (The Example of Kardzhali), Assen Zlatarov University Annual, Vol. XLV, Book 2, Burgas, 2016, pp. 248-250, ISSN 1312-1359

Hasan Azis, (2018b). Quality and perspectives for administrative management development according to the decentralization process in Greece, Public archive, Svistov, vol.3, 2018 0323-9004 (print), 2367-9301 (online)

Hasan Azis, (2016b), Naglasi i udovletvorenost spryamo detsentralizatsiyata v Bulgaria, Psihologichni izsledvania, Volume 19, Number 2, 2016, str. 99-111, ISSN 1311-4700 (print), ISSN 2367-4563 (online)

Liebmann, Marian (ed). (2000a). Mediation in Context. Jessica Kingsley Publishers

Madiation Act. Pibl. (2000b). SG, No. 110/ 17.12.2004, last amend. and suppl., SG No. 17/26.02.2019. https://lex.bg/laws/ldoc/2135496713 (available on 30 May 2020).

Petrova Teodora, Petrov Zhivo, (2020a). Alternative Approaches for Long-Term Defence Planning, Proceedings of SOCIOINT 2020-7th International Conference on Advances in Education and Social Sciences, 20-22 January, 2020-Dubai, U.A.E., pp. 818-825, ISBN 978-605-82433-8-5

Petrova Teodora, Petkova-Georgieva Stoyanka, (2020b). Motivatsionen model za razvivane na savremenen meditsinski turizam, Elektronno spisanie "SCIENTIFIC ATLAS", 2020, № 1, ISSN 2738-7518

Po Allahverdova, O.V., Karpenko, A. D. (1999). Mediatsiya. Izd. Sankt Petrburkgskiy Tsentr razresheniya konfliktov. SPb. 1999. s. 4-55. 
Phillips, Barbara. (2001). The Mediation Field Guide. Jossey-Bass, p. 8

Vassilev, V., Tanev D., Kavrakov T., Abrashev H., (2015). Our experience in surgical treatment of the complicated forms of colorectal cancer, Trakia journal of scientific, ISSN 1313-7050, 2015

Vassilev V., Kavrakov T., (2014). Diabetic foot - phenomenon or complications of diabetes, International scientific on-line journal "Science \& Technologies", Publisher "Union of Scientists - Stara Zagora", IV; $1 ; 2014$, ISSN 1314-4111 